Article

\title{
Raising Awareness on Health Impact of the Chemicals Used in Consumer Products: Empirical Evidence from East-Central Europe
}

\author{
Florin-Alexandru Luca ${ }^{1}$, Claudia-Ioana Ciobanu ${ }^{1}$, Andreia Gabriela Andrei ${ }^{2, *}$ (1) and \\ Adrian V. Horodnic ${ }^{3}$ \\ 1 Management BMTM, Faculty of Civil Engineering and Building Services, "Gheorghe Asachi” Technical \\ University of Iași, Iași 700050, Romania; florin.alexandru.luca@tuiasi.ro (F.-A.L.); \\ claudia.ciobanu@tuiasi.ro (C.-I.C.) \\ 2 Interdisciplinary Research Department of Social Sciences and Humanities, Alexandru Ioan Cuza University, \\ Iasi 700506, Romania \\ 3 Department of Behavioral Sciences, Faculty of Medicine, Grigore T. Popa University of Medicine and \\ Pharmacy, Iași 700115, Romania; adrian-vasile-horodnic@umfiasi.ro \\ * Correspondence: andrei.andreia@gmail.com; Tel.: +40-722-988-574
}

Received: 16 November 2017; Accepted: 15 January 2018; Published: 16 January 2018

\begin{abstract}
Recent research and guidance provided by regulatory authorities address the growing concerns on the control of chemicals used in consumer products. In this context, this study responds to literature alerts emphasizing the need for promoting risk reduction by decreasing the use of damaging chemicals and raising public awareness on this issue. It focuses on East-Central Europe and investigates whether consumers are worried about the impact on health of chemicals, and whether they think there is enough information available in this sense. The study uses logistic regression in order to analyze the secondary data from Special Eurobarometer No. 416 (part of Eurobarometer Wave EB 81.3, European Commission, 2014), namely 27,998 interviews collected in all 28 EU countries, of which 11,460 are from East-Central Europe. The research reveals a profile of East-Central Europeans, who consider that they lack information on the topic, and identifies the most effective way of reaching these people according to their perceptions and habits. Reporting results on a representative sample in East-Central Europe, the study indicates the channels, sources of information, and trusted institutions in order to support a campaign for raising public awareness on the health impact of chemicals used in consumer products.
\end{abstract}

Keywords: sustainable action; public awareness; consumer protection; health; chemicals in consumer products; regulatory standards; East-Central Europe

\section{Introduction}

Environmental and health issues are key concerns for modern society. Both public authorities and consumers display a significant interest towards this issue. Although technology generates economic development, we should also consider its impact on the natural resources of the planet due to the fact that this process implies an upgrade of used production methods and, implicitly, the use of chemicals [1]. Chemicals in products used daily may have a significant impact on both human health and the well-being of the planet, as these remain for a long time in the environment. This has been the subject of various international legislative initiatives. Together with pollution and depletion of natural resources, it is a key concern for the European Union citizens. With $43 \%$ of EU28 citizens concerned about the impact of chemicals on human health [1], this has become a subject of interest not only for policy-makers, but also for non-governmental organizations advocating for increased awareness and a radical change of attitude. 
Several international institutions, such as the European Chemicals Agency or the European Food Safety Authority initiated studies identifying toxic chemical substances used in the composition of consumer products. As this information becomes available and widespread, it justifies the initiation of further studies exploring the impact of specific chemicals on human health. Although regulatory agencies and authorities are formally involved in providing guidance (for instance, REACH Regulation in EU), there are still unknown features and debates on the use of certain substances [2].

Chemicals are present in almost all manufactured products: electronics, cosmetics, cleaning products, building materials, and clothes [3-5]. Table A1 in the Appendix A summarizes the main chemical substances included in dairy products (milk, yogurt, cream cheese), processed meats, refreshments, drinks, pasta, canned foods, other long-life edible products [6-9], furniture and home-based industrial products [10-13], buildings and construction industry [14-17], agricultural products and pests management [7,18], polish and other products of domestic use [19-21], and lubricants and oil derivatives $[22,23]$. It has been agreed that both consumers and the environment are exposed to emissions from products that include these chemicals [24-26], even if their contribution to the technological development of our society is undeniable.

It can also be argued that chemicals are essential for the development of a modern society and that their use can bring substantial benefits, such as an improved quality of life [27]. However, it is obvious that, aside from these benefits, there are negative effects that damage our biological system and cannot be neglected $[5,26,28]$.

The interaction between the members of our society and chemical industry generates complex and controversial perceptions that are influenced by such social factors as: education, social media environment, revenue, social status, urban or rural residence or geographic area $[6,11,29]$. In order to analyze the nature of this relationship, it is important to identify the view that each member of society holds when expressing its opinion on the use of chemicals in products. Therefore, for the end users of the products, the opinion on the use of chemicals may range from useful to dangerous, and is influenced by the level of knowledge and education of every person. Those who are informed about the hazardous effects of chemicals on human health and the environment have a negative opinion about the use of products that contain chemicals, and others who are not informed properly see these products as being useful and a source of technological and economic development. The last category also reports positive economic benefits from the growth of employment rate [29].

The perceptions of individuals can be also influenced by the geographical proximity to the chemical industry. People who live in highly-industrialized areas may interact significantly with such products and view them as polluters or as accidents waiting to happen. For people who live in less industrialized areas, the may base their perceptions on the product's use and indirectly on what they hear from mass media or other people [29].

The answer to these negative aspects mentioned above resides in achieving a sustainable economic development by using substitutable substances that are less harmful for the environment and also for the human health [11,21], and by improving the legislative framework regulating the use of chemicals in products $[14,20]$. The companies complying with these legislative directives can obtain a competitive advantage in the market compared to the companies that follow only the minimal mandatory requirements [16].

Due to technological development of instruments facilitating public communication and implicitly the raise of public awareness, the use of chemicals in products is considered by some researchers to be well-controlled nowadays $[6,14,20]$. Although financial incentives that can be provided by the chemical industry are substantial, the harmful negative effects must be recognized and prevented by raising public awareness through mass media and social media [16]. Social wellness and human development are seen nowadays as depending on technological advances and on assumed behavior of citizens who are aware of the harmful effect of certain chemicals [29].

Since 1950, public institutions and NGOs have been organizing awareness campaigns on the negative impact of chemicals on human health $[26,30]$. Chemical exposure is connected to many severe 
human disorders, such as cancer [26,30,31], asthma [24], endocrine diseases [26], or neurobehavioral problems [32]. To assess the risk generated by the exposure to chemicals, complex, expensive, and time-consuming tests are required [33-35]. This is because the details about the chemical content of products are not always available to consumers, organizational buyers, or regulators who evaluate the risks of using these products in our everyday life [2]. The growing concerns about the control and use of these chemicals are further amplified if we consider their impact on the natural environment $[4,27,36]$. In this context, researchers in the field of consumption began to take interest in environmental topics [28]. For example, starting with 1970, new environmental fields, such as ecological economics and industrial ecology have been developed [36].

Human perception as regards the relation between environment and health across specific scales (natural, neighborhood, and home) has been analyzed to gauge public awareness on the consequences of chemical exposure [30]. The findings indicate that people believe that home and neighborhood can be managed more easily than the wider natural environment, and are not seen as a substantial risk for the health of individuals. This demonstrates that there is a real need to increase public awareness of environmental and health issues as people should be informed about the harmful effects of cleaning products and pesticides used in their immediate vicinity. Various studies analyzed perceptions on the harmful effects of chemical substances on human health, the environment or both. All these studies emphasized the importance of individual perceptions on the use of chemicals in everyday products. In turn, these perceptions inform attitudes, and attitudes shape the ways in which people respond to public policy initiatives [26,30].

Although this is an ongoing concern for academic researchers, recent studies demonstrate that knowledge on the hazards and risks associated with the use of chemicals continues to be very limited $[5,28]$.

It is also a concern for governmental institutions. For example, in the United States, the Chemical Safety Improvement Act (2013)—an upgraded version of the Toxic Substances Control Act (1976)—was adopted by the Environmental Protection Agency (EPA). In Europe, regulations on the Registration, Evaluation, Authorization and Restriction of Chemicals (REACH) were introduced in 2007 by the European Chemicals Agency. Researchers analyzed these two regulations and agreed that regulatory standards in Europe are tighter $[5,26]$ and more easily accessible by consumers than their American equivalents [28]. Chemical manufacturers, however, favor US regulations when compared to the EU [2]. The International Chemicals Management (SAICM) is the legislation that seeks to minimize the risks associated with the use of chemicals. It demands increased consumer/customer access to information connected to the chemical content in products by using a unified database [2]. However, as different regions of the world vary in their degree of economic development, the absence of an internationally standardized approach to this issue can be easily noticed $[28,33,37]$. Details on the legislation in the European Union applied for rational use of chemicals in consumer products $[2,28,38-43]$ are provided in Table A2 in the Appendix A.

Another reason that can justify the lack of standardized information is that segments of audience have specific informational needs and legislation cannot meet all of them. For example, from a consumer perspective, the information related to health risks of using a product containing specific chemical substances is important. Meanwhile, recyclers need to understand the information related to the recommended management of a specific product (e.g., if incineration or crushing is needed). At the same time, manufacturers are interested in the presence of chemicals because they want to produce competitive goods and comply with the legislation regarding environmental protection. Therefore, the development of a complex, internationally-standardized system needs to consider all these different requirements. Furthermore, to control the use of hazardous chemicals in products, a risk management strategy should effectively handle the issue of combinations of chemicals as well [2,25].

Researchers also analyzed the recommendations of the regulatory legislative framework that could be used to mitigate the risks of using chemical substances. Organizing consumer awareness campaigns is just one approach that should be considered, along with finding the right methods for substance substitution or efficient waste management [33]. 
Widely accessible studies from many national and international organizations explain the effect the chemicals used in consumer products have on human health [35]. The Campaign for Safe Cosmetics is a non-profit advocacy group, which launched legislative proposals and consumer campaigns aimed to inform consumers about the harmful effects of chemicals used to obtain cosmetics. As an answer to these initiatives, some companies changed the composition of baby products (e.g., Johnson and Johnson-New Brunswick, NJ, USA). Other organizations, such as Safer Chemicals, Healthy Families, The American Nurses Association (ANA) and The American College of Obstetricians and Gynecologists (ACOG) advanced healthier alternatives. To maintain customer loyalty, well-known companies, such as Gatorade (Chicago, IL, USA), Walmart (Bentonville, AR, USA), Target (Minneapolis, MN, USA), or Procter and Gamble (Cincinnati, OH, USA) agreed to stop using some chemicals, such as synthetic growth hormone rBGH, bisphenol, or dibutyl phthalate (DBP), which were considered harmful for human health [26].

To develop a consumer guidance process, it is important to examine what people already know about the use of chemicals in consumer products, if they are worried about the impact of chemicals on health, and whether they think there is enough available information in this sense or, conversely, do people feel they lack information about the impact on their health of chemicals used in everyday products?

Our objectives are, therefore:

(1) To identify a profile of East-Central Europeans (socio-economic and spatial characteristics) who are more likely to consider that they lack information about the impact of chemicals on human health and are more willing to receive such information.

(2) To indicate the adequate communication channels and institutions to support an information campaign for raising awareness on health impact of chemicals used in consumer product based on our findings regarding perceived credibility of information sources on this issue and media consumption habits in the countries of the East-Central European area.

\section{Materials and Methods}

In analyzing which people in East-Central Europe are more likely to believe that they lack information on the impact on health of chemicals used in everyday products and to discover the most appropriate sources of information and trusted institutions for promoting an awareness campaign, we used in this study data from Special Eurobarometer No. 416 ('Attitudes of European citizens towards the environment'), as part of Eurobarometer Wave EB 81.3 [44]. Covering the population aged 15 and over in the 28 European Union Member States, the survey was conducted between 26 April and 11 May 2014, in the respondent's national language, comprising 27,998 face-to-face interviews. Of the total, 11,460 were conducted in East-Central Europe, with about 1000 interviews in each country.

For ensuring that on the issues of gender, age, region and size of locality, the sample was representative for the population to which it belongs, a multi-stage, random (probability) sampling methodology was used, along with a national weighting procedure. The weighting scheme ensures that the sample is representative by correcting for sub/supra represented populations (details in the Special Eurobarometer No. 416 methodology [44]). However, considering the debate on using weights for multivariate analyses we, therefore, used the weighting scheme only for the univariate analysis in order to obtain representative results as recommended in Eurobarometer methodology and in literature [45]. The same approach was previously used in other studies using Eurobarometer surveys (e.g., [46-48]).

In order to find valuable information for an awareness campaign, the dependent variable is whether individuals in East-Central Europe consider that they lack information about the impact of chemicals on health. This is based on those who choose 'the impact on our health of chemicals used in everyday products' among the five main environmental issues where information is lacking. Accordingly, considering that the dependent variable is a dummy variable, with recorded value 1 for those selecting the chemicals impact on health and with value 0 otherwise, we have used logistic regression analysis. 
The selected independent variables can be grouped in four categories: socio-economic variables, spatial characteristics, variables related to the sources of information about environmental issues and variables related to trusted institutions for providing reliable information about environmental issues. Hence, gender (dummy variable: male, female), age group (categorical variable: 15-24 years, 25-39 years, 40-54 years, 55 years and older), employment (categorical variable: self-employed, employed, not working), and problems in paying bills (categorical variable: most/from time to time, almost never/never) were used for analyzing the socio-economic profile of the respondent, while type of community (categorical variable: rural area, small/middle-sized town, large town) and country of residence (categorical variable: Hungary, Czech Republic, Estonia, Latvia, Lithuania, Poland, Slovakia, Slovenia, Bulgaria, Romania, Croatia) were used for analyzing spatial variations. Dummy variables were used for the following sources of information on environmental issues: newspapers; magazines; radio; television news; films and documentaries on television; books; publications, brochures or information materials; Internet (websites, blogs etc.); social media; events (conferences, exhibitions, festivals etc.); conversations with relatives, family, friends, neighbors, or colleagues. Finally, in order to analyze trusted institutions for providing reliable information regarding environmental issues, dummy variables were also used in the following entities: companies, trade unions, national government, regional or local government, European Union, and International organizations (e.g., United Nations).

For reporting the findings, firstly was emphasized the importance of impact on health of chemicals amongst the main issues that people living in East-Central Europe are worried about. Secondly, descriptive statistics and, thirdly, logistic regressions were used to identify the respondents who are more likely to report lacking information on the impact of chemicals on health in East-Central Europe and to explore sources of information and trusted institutions for promoting a marketing campaign designed to increase awareness among the population and to support public health policies.

\section{Results}

To start assessing whether the impact of chemicals used in everyday products is a source of serious concern, Figure 1 reports the issues that are most worrying for European citizens.

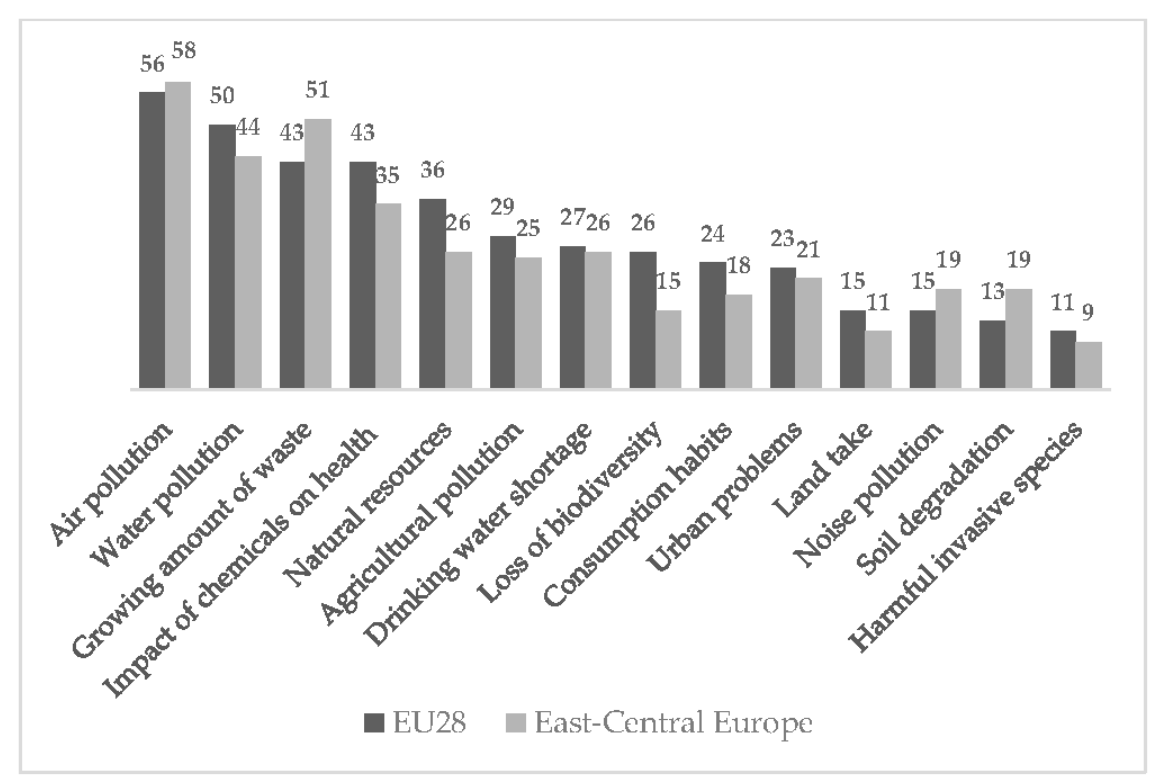

Figure 1. Main environmental concerns in EU28 and East-Central Europe $(n=27,998)$.

Overall, at EU-28 level, the most common responses relate to air pollution (56\% of Europeans being worried about air pollution), water pollution (50\%), waste generation (43\%), and the impact of chemicals on health (43\%). Similar results are obtained when analyzing the main environmental 
issues in East-Central Europe. Half or more of the citizens in East-Central Europe are worried about air pollution (58\%) and growing amount of waste (51), followed by water pollution (44\%) and the impact on health of the chemicals used in everyday products (35\%). Indeed, Figure 1 reveals that the impact on health of chemicals used in everyday life is a source of serious concern at both EU-28 level and East-Central Europe level. In comparison, people in these regions are least worried about noise pollution (15\% and $19 \%)$, soil degradation (13\% and $19 \%$ ) or harmful invasive species $(11 \%$ and $9 \%)$.

However, is it the case that the impact on health of chemicals is considered a serious concern in all countries in East-Central Europe? Table 1 reports the variations by country.

Table 1. Main environmental concerns in East-Central Europe, by country $(n=11,460)$.

\begin{tabular}{|c|c|c|c|c|c|c|c|c|c|c|}
\hline \multirow[t]{2}{*}{ Region/Country } & \multicolumn{2}{|c|}{ Air Pollution } & \multicolumn{2}{|c|}{$\begin{array}{c}\text { Growing Amount } \\
\text { of Waste }\end{array}$} & \multicolumn{2}{|c|}{ Water Pollution } & \multicolumn{2}{|c|}{$\begin{array}{c}\text { Impact of Chemicals } \\
\text { on Health }\end{array}$} & \multicolumn{2}{|c|}{ Natural Resources } \\
\hline & $\%$ & Rank & $\%$ & Rank & $\%$ & Rank & $\%$ & Rank & $\%$ & Rank \\
\hline $\begin{array}{l}\text { East-Central } \\
\text { Europe }\end{array}$ & 58 & 1 & 51 & 2 & 44 & 3 & 35 & 4 & 26 & 5 \\
\hline Hungary & 68 & 1 & 59 & 2 & 49 & 3 & 30 & 5 & 33 & 4 \\
\hline Czech Republic & 55 & 2 & 61 & 1 & 44 & 3 & 35 & 4 & 33 & 5 \\
\hline Estonia & 47 & 3 & 52 & 1 & 47 & 4 & 48 & 2 & 31 & 5 \\
\hline Latvia & 49 & 4 & 53 & 3 & 61 & 1 & 53 & 2 & 25 & 5 \\
\hline Lithuania & 64 & 1 & 54 & 3 & 53 & 4 & 63 & 2 & 19 & 5 \\
\hline Poland & 56 & 1 & 54 & 2 & 37 & 3 & 32 & 4 & 24 & 5 \\
\hline Slovakia & 53 & 2 & 55 & 1 & 48 & 3 & 41 & 4 & 30 & 5 \\
\hline Slovenia & 60 & 1 & 49 & 2 & 49 & 3 & 42 & 4 & 27 & 5 \\
\hline Bulgaria & 62 & 1 & 42 & 3 & 51 & 2 & 40 & 4 & 28 & 5 \\
\hline Romania & 60 & 1 & 37 & 3 & 45 & 2 & 33 & 4 & 24 & 5 \\
\hline Croatia & 58 & 1 & 55 & 2 & 48 & 3 & 39 & 4 & 29 & 5 \\
\hline
\end{tabular}

Note: ranks calculated considering the percent with two decimals.

For instance, in Poland, air pollution is cited as the main environmental concern (cited by $56 \%$ ), followed by the growing amount of waste (54\%), water pollution (37\%), impact of chemicals on health $(32 \%)$, and the depletion of natural resources $(24 \%)$. Indeed, whether one examines solely the Baltic countries, the finding is that people living in this area are more likely to be worried about the impact on health due to chemicals in everyday products when compared to East-Central Europe average ( $48 \%$ in Estonia, 53\% in Latvia, and 63\% in Lithuania, compared to East-Central Europe average of 35\%). Nevertheless, a closer investigation reveals that in Baltic countries the impact of chemicals on health was the second most frequently cited environmental issue (behind remaining the growing amount of waste in Estonia, water pollution in Latvia, and air pollution in Lithuania), whilst it was ranked fifth only in Hungary. In East-Central Europe as a whole, the impact of chemicals on health was ranked fourth amongst main environmental concerns, showing the environmental concerns of people in this region.

Whilst always ranked among the first four main environmental concerns in East-Central Europe, the impact of chemicals on health is the issue about which almost one third of people would like to receive more information. Table 2 shows that $32 \%$ of respondents in East-Central Europe stated that they lack information about the impact on health of chemicals used in everyday products.

To start to evaluate who is more likely to report lacking information about the impact of chemicals on health in East-Central Europe, Table 2 reports the variations by socio-economic and spatial characteristics. It reveals that $31 \%$ of men and $32 \%$ of women stated that they lack information about the impact on health of chemicals used in everyday products. Similarly, those aged 14-24 seem to be more likely to lack information about the impact on health of chemicals than the ones aged over 54 (34\% compared to $30 \%$ ), and respondents having most of the time difficulties in paying household bills seem to be more likely to lack such information than the respondents never or seldom having difficulties in paying bills (35\% compared to 31\%). The employed would like to have more information about the impact on health of chemicals (33\%), as well as the respondents living in small or middle-sized towns (36\%). These results are further supported by findings in Table 2 on respondents stating that they feel well-informed about environmental issues in general. 
Turning to spatial characteristics, Table 2 shows the differences between countries in East-Central Europe to the extent to which respondents think they lack information about the impact of chemicals on health. This reveals that people in Lithuania (48\%), Slovenia (42\%), Bulgaria (40\%), Slovakia, and Latvia (39\%) would like to receive more information about the impact on health of chemicals.

Table 2. Health impact of chemicals-lack information, by socio-economic and spatial characteristics $(n=11,460)$.

\begin{tabular}{|c|c|c|c|c|c|c|c|}
\hline \multirow{2}{*}{\multicolumn{2}{|c|}{$\begin{array}{c}\text { Socio-Economic and Spatial } \\
\text { Characteristics }\end{array}$}} & \multirow{2}{*}{$\begin{array}{c}\text { Impact of Chemicals } \\
\text { on Health-Lack } \\
\text { Information }\end{array}$} & \multicolumn{5}{|c|}{ Informed about Environmental Issues } \\
\hline & & & $\begin{array}{c}\text { Very Well } \\
\% \\
\end{array}$ & $\begin{array}{c}\text { Fairly } \\
\text { Well } \\
\%\end{array}$ & $\begin{array}{c}\text { Fairly } \\
\text { Badly }\end{array}$ & $\begin{array}{c}\text { Very } \\
\text { Badly }\end{array}$ & $\begin{array}{c}\begin{array}{c}\text { Don't } \\
\text { Know }\end{array} \\
\%\end{array}$ \\
\hline$E U-28$ & & 32 & 9 & 53 & 29 & 6 & 3 \\
\hline Gender & Men & 31 & 10 & 53 & 28 & 6 & 3 \\
\hline \multirow{3}{*}{$\begin{array}{l}\text { Age group } \\
\text { (years) }\end{array}$} & $25-39$ & 33 & 8 & 53 & 30 & 6 & 4 \\
\hline & $40-54$ & 32 & 9 & 54 & 28 & 6 & 3 \\
\hline & $55+$ & 30 & 8 & 52 & 29 & 7 & 4 \\
\hline \multirow{2}{*}{$\begin{array}{l}\text { Employment } \\
\text { status }\end{array}$} & Self-employed & 30 & 13 & 57 & 22 & 5 & 3 \\
\hline & Employed & 33 & 8 & 55 & 29 & 5 & 3 \\
\hline \multirow{3}{*}{$\begin{array}{l}\text { Type of } \\
\text { community }\end{array}$} & Rural area or village & 29 & 10 & 53 & 27 & 7 & 3 \\
\hline & Small/Middle town & 36 & 7 & 52 & 31 & 6 & 4 \\
\hline & Large town & 32 & 8 & 54 & 30 & 5 & 3 \\
\hline \multirow{9}{*}{ Country } & Hungary & 28 & 9 & 60 & 25 & 6 & 0 \\
\hline & Czech Republic & 36 & 7 & 41 & 40 & 11 & 1 \\
\hline & Estonia & 38 & 5 & 64 & 28 & 2 & 1 \\
\hline & Latvia & 39 & 6 & 59 & 30 & 4 & 1 \\
\hline & Lithuania & 48 & 5 & 56 & 33 & 5 & 1 \\
\hline & Poland & 27 & 7 & 58 & 24 & 3 & 8 \\
\hline & Slovakia & 39 & 8 & 50 & 32 & 8 & 2 \\
\hline & Slovenia & 42 & 15 & 67 & 16 & 2 & 0 \\
\hline & Croatia & 35 & 12 & 54 & 28 & 6 & 0 \\
\hline
\end{tabular}

To start identifying sources of information and trusted institutions for promoting a marketing campaign designed to increase the awareness among the population and support public health policies, Table 3 reports the trusted institutions and sources of information frequently used by individuals who consider they lack information about the impact of chemicals on health.

Analyzing the results in Table 3, the finding is that $67 \%$ of those who consider they lack information about the impact of chemicals on health cited television news as the main source of information about the environment, $40 \%$ cited the Internet (website, blogs, etc.), $32 \%$ cited films and documentaries on television, $28 \%$ cited newspapers, and $24 \%$ cited radio as one of their main sources of information. Relatively few people reported that their main sources of information about environmental issues include books $(6 \%)$ or events (3\%). When investigating the trusted institutions in Table 3 , the finding is that $12 \%$ of those who consider they lack information about the impact of chemicals on health expressed trust in the information provided by international organizations, and $11 \%$ showed trust in the information provided by the European Union.

Therefore, by analyzing these descriptive statistics, the tentative conclusion is that small variations exist between socio-demographic groups when dealing with a lack of information about the impact of chemicals on health. However, cross-national variations can be noticed, as well as notable differentiation between sources of environmental information and trusted institutions. To test whether these associations are significant when other variables are taken into account and held constant, Table 4 reports the results of a logistic regression analysis. 
Table 3. Sources of information and trusted institutions (individuals who consider they lack information about the impact of chemicals on health; $n=4208$ ).

\begin{tabular}{cccc}
\hline \multicolumn{4}{c}{ Information about Environmental Issues } \\
\hline Sources of Information & $\%$ & Trusted Institutions & $\%$ \\
\hline Television news & 67 & International organizations & 12 \\
Internet (websites, blogs etc.) & 40 & European Union & 11 \\
Films and documentaries on television & 32 & Regional or local government & 6 \\
Newspapers & 28 & National government & 4 \\
Radio & 24 & Companies & 2 \\
Conversations with relatives, family etc. & 15 & Trade unions & 2 \\
Publications, brochures etc. & 10 & & \\
Magazines & 9 & & \\
Social media & 9 & & \\
Books & 6 & & \\
Events (conferences, exhibitions etc.) & 3 & & \\
\hline
\end{tabular}

Table 4 shows that an additive model is used. Model 1 in Table 4 evaluates the socio-economic variables (gender, age, employment status, problems paying bills) to examine their association with the propensity to lack information about the impact on health of chemicals, while Model 2 in Table 4 adds the spatial variables (type of community and country) alongside the socio-economic variables. Model 3 and Model 4 in Table 4 add the sources of information about environmental issues and trusted institutions for providing reliable information about the environmental issues to the socio-economic and spatial variables.

Model 1 in Table 4 reveals that women are significantly more likely to consider they lack information about the impact of chemicals on health than men. No significant relationship is found between the propensity to lack information and other socio-economic variables (age, employment status, problems paying bills). When adding spatial variables in Model 2 in Table 4, the additional finding is that people living in the Czech Republic, Estonia, Latvia, Lithuania, Slovakia, Slovenia, Bulgaria, Romania, and Croatia are significantly more likely to consider they lack information about the health impact of chemicals than those living in Hungary. However, no significant relationship is found with the type of community.

Furthermore, Model 3 in Table 4 reveals that respondents using films and documentaries on television, Internet (other websites, blogs etc.), conversations with relatives, family, friends, neighbors or colleagues, publications, brochures or information materials, social media, television news, newspapers, and radio as the main sources of information about environmental issues are significantly more likely to report lacking information about the impact of chemicals on health. These sources of information would be appropriate for promoting a marketing campaign designed to increase awareness among those who would like to have more information about the impact on health of chemicals. Model 4 in Table 4 shows that people who trust the information provided by the European Union and international organizations are significantly more likely to consider they lack information about the impact of chemicals on health. Similarly, these institutions would be reliable institutions for providing information about the impact of chemicals used in everyday products. 
Table 4. Logistic regressions of the propensity to lack information about the impact of chemicals on health in East-Central Europe.

\begin{tabular}{|c|c|c|c|c|}
\hline Variables & Model 1 & Model 2 & Model 3 & Model 4 \\
\hline Female & $0.129^{* * *}(0.040)$ & $0.105^{* *}(0.041)$ & $0.085^{* *}(0.041)$ & $0.085^{* *}(0.041)$ \\
\hline \multicolumn{5}{|l|}{ Age group (CG: 15-24 years) } \\
\hline $25-39$ years & $-0.057(0.078)$ & $-0.035(0.079)$ & $0.014(0.080)$ & $0.018(0.081)$ \\
\hline $40-54$ years & $-0.013(0.078)$ & $-0.016(0.079)$ & $0.059(0.081)$ & $0.069(0.081)$ \\
\hline 55 years and older & $-0.044(0.070)$ & $-0.066(0.071)$ & $0.067(0.075)$ & $0.080(0.076)$ \\
\hline \multicolumn{5}{|c|}{ Employment (CG: Self-employed) } \\
\hline Employed & $0.067(0.080)$ & $0.053(0.081)$ & $0.059(0.082)$ & $0.064(0.082)$ \\
\hline Not working & $-0.059(0.084)$ & $-0.053(0.085)$ & $0.013(0.086)$ & $0.019(0.086)$ \\
\hline \multicolumn{5}{|c|}{ Problems paying bills (CG: Most of the time) } \\
\hline From time to time & $-0.101(0.064)$ & $-0.050(0.065)$ & $-0.087(0.066)$ & $-0.088(0.066)$ \\
\hline Almost never/Never & $-0.057(0.059)$ & $0.027(0.062)$ & $-0.039(0.063)$ & $-0.044(0.063)$ \\
\hline \multicolumn{5}{|c|}{ Type of community (CG: Rural area or village) } \\
\hline Small/Middle town & & $0.048(0.048)$ & $0.039(0.048)$ & $0.035(0.048)$ \\
\hline Large town & & $0.060(0.051)$ & $0.016(0.052)$ & $0.003(0.052)$ \\
\hline \multicolumn{5}{|l|}{ Country (CG: Hungary) } \\
\hline Czech Republic & & $0.373^{* * *}(0.095)$ & $0.289^{* * *}(0.096)$ & $0.293^{* * *}(0.096)$ \\
\hline Estonia & & $0.454^{* * *}(0.094)$ & $0.411^{* * *}(0.096)$ & $0.433 * * *(0.096)$ \\
\hline Latvia & & $0.485^{* * *}(0.095)$ & $0.467^{* * *}(0.097)$ & $0.490 * * *(0.097)$ \\
\hline Lithuania & & $0.875^{* * *}(0.094)$ & $0.883 * * *(0.095)$ & $0.890^{* * *}(0.095)$ \\
\hline Poland & & $-0.064(0.100)$ & $0.011(0.102)$ & $0.024(0.103)$ \\
\hline Slovakia & & $0.557^{* * *}(0.095)$ & $0.515^{* * *}(0.097)$ & $0.522 * * *(0.097)$ \\
\hline Slovenia & & $0.631^{* * *}(0.094)$ & $0.641^{* * *}(0.095)$ & $0.659^{* * *}(0.096)$ \\
\hline Bulgaria & & $0.554^{* * *}(0.095)$ & $0.602 * * *(0.097)$ & $0.594^{* * *}(0.097)$ \\
\hline Romania & & $0.180 *(0.096)$ & $0.204^{* *}(0.098)$ & $0.213^{* *}(0.098)$ \\
\hline Croatia & & $0.380^{* * *}(0.097)$ & $0.334^{* * *}(0.098)$ & $0.332 * * *(0.098)$ \\
\hline \multicolumn{5}{|c|}{ Sources of information about environmental issues } \\
\hline Newspapers & & & $0.211^{* * *}(0.046)$ & $0.204^{* * *}(0.046)$ \\
\hline Magazines & & & $0.103(0.070)$ & $0.096(0.070)$ \\
\hline Television news & & & $0.328^{* * *}(0.050)$ & $0.318^{* * *}(0.051)$ \\
\hline Radio & & & $0.175^{* * *}(0.049)$ & $0.173^{* * *}(0.049)$ \\
\hline Films and documentaries & vision & & $0.612 * * *(0.049)$ & $0.597^{* * *}(0.049)$ \\
\hline Conversations with relativ & iily, friends, neighb & or colleagues & $0.386^{* * *}(0.062)$ & $0.381^{* * *}(0.062)$ \\
\hline Books & & & $0.090(0.094)$ & $0.086(0.095)$ \\
\hline Publications, brochures & mation materials & & $0.351^{* * *}(0.074)$ & $0.339 * * *(0.075)$ \\
\hline Events (conferences, ex & ns, festivals etc.) & & $0.032(0.116)$ & $0.007(0.117)$ \\
\hline Social media & & & $0.347^{* * *}(0.073)$ & $0.328^{* * *}(0.074)$ \\
\hline Internet (other we & blogs etc.) & & $0.401^{* * *}(0.050)$ & $0.388^{* * *}(0.050)$ \\
\hline \multicolumn{5}{|c|}{ Trusted institutions for providing reliable information about environmental issues } \\
\hline National government & & & & $-0.086(0.100)$ \\
\hline Regional or local governm & & & & $-0.097(0.083)$ \\
\hline European Union & & & & $0.152 * *(0.071)$ \\
\hline International organizatic & ited Nations etc.) & & & $0.142^{* *}(0.065)$ \\
\hline Companies & & & & $-0.223(0.156)$ \\
\hline Trade unions & & & & $0.154(0.134)$ \\
\hline Constant & $-0.517^{* * *}(0.116)$ & $-1.002^{* * *}(0.140)$ & $-1.824^{* * *}(0.158)$ & $-1.833^{* * *}(0.159)$ \\
\hline Observations & 11,285 & 11,282 & 11,282 & 11,282 \\
\hline Pseudo $\mathrm{R}^{2}$ & 0.0015 & 0.0131 & 0.0287 & 0.0298 \\
\hline Log likelihood & -7412.9625 & -7324.3064 & -7208.4667 & -7200.6664 \\
\hline$x^{2}$ & 21.53 & 195.01 & 426.69 & 442.29 \\
\hline$p>$ & 0.0059 & 0.0000 & 0.0000 & 0.0000 \\
\hline
\end{tabular}

Notes: Significant at ${ }^{* * *} p<0.01,{ }^{* *} p<0.05,{ }^{*} p<0.1$; Standard errors in parentheses; CG: comparison group.

\section{Discussion and Conclusions}

According to research objectives, the present study focused on finding-out the most appropriate channels, sources of information, and trusted institutions to be used to support an awareness-raising campaign related to the impact on health of chemicals which are incorporated in some of the products consumers use in their everyday life.

To this end, the study used secondary data provided by Special Eurobarometer No. 416 ('Attitudes of European citizens towards the environment'), as part of Eurobarometer Wave EB 81.3 [44]. Based on 
a representative sample of 27,998 face-to-face interviews collected in all 28 EU countries, of which 11,460 were in East-Central European countries, the study aimed to identify which consumers in East-Central Europe are more likely to consider they lack information on a topic of major concern, such as the impact on health of chemicals used in everyday products, and to reveal the most effective ways of informing these consumers about the impact of chemicals in everyday products.

Aside from comparing the overall results derived from all $28 \mathrm{EU}$ countries with East-Central European countries regarding the concerns of citizens towards environmental issues, the study employs logistic regression to identify a profile of consumers from East-Central Europe who are more likely to consider that they lack information about the impact on health of chemicals used in consumer products. The study revealed the channels and sources of information used, as well as the details concerning the institutions they trust. Simultaneously with identifying the socio-economic profile of consumers who perceive that they lack information about this issue, the study suggests effective ways of supporting a campaign for raising public awareness in the East-Central Europe area regarding the impact on health of the chemicals used in consumer products.

Therefore, the findings of the present study align with previous literature emphasizing the increasing use of chemicals in the products consumed in everyday life [31], and the justified trend of initiating further research exploring the perceived impact of different chemical compounds on human health [32].

Although there are regulatory authorities that are engaged in providing guidance $[27,28,44]$, there are still a lot of gaps and debates about the use of certain chemical compounds on a large scale.

However, these regulatory approaches could be used to promote risk reduction of using damaging chemicals in consumer products by organizing well-targeted campaigns for raising public awareness. Although the literature $[45,49]$ emphasized that these campaigns are highly needed, our research is one of the few studies revealing which are the most appropriate sources of information and trusted institutions for supporting an information campaign aimed to raise awareness about the impact on health of chemicals used in consumer products.

Therefore, the state-of-the-art calls for fine-grained insights into future theoretical and practical initiatives. Further studies are expected to describe more deeply the impact of various products on the health of individuals and the community welfare. Simultaneously, the emergence of better consumer protection represents a step forward for human health [27,28,37]. Taking no action triggers a high-risk potential for human health, and cannot be overlooked by regulatory institutions, society representatives, mass media, businesses, etc., as different studies have consistently emphasized [50-53].

This study shows that the impact on health of chemicals used in everyday life is a source of serious concern in both EU-28 and East-Central Europe. This study reveals that in Baltic countries the impact on health of chemicals was the second most frequently cited environmental concern. In East-Central Europe, as a whole, the impact on health of chemicals was ranked fourth amongst main environmental concerns, and about one third of the population is willing to receive more information.

The logistic regression revealed that women are significantly more likely than men to believe they lack information about the impact of chemicals on health and also that people living in the Czech Republic, Estonia, Latvia, Lithuania, Slovakia, Slovenia, Bulgaria, Romania, and Croatia are significantly more likely to consider that they lack information about the impact on health of chemicals than in Hungary.

The study also shows that citizens using films and documentaries on television, Internet (other websites, blogs etc.), conversations with relatives, family, friends, neighbors or colleagues, publications, brochures or information materials, social media, television news, newspapers, and radio as main sources of information about environmental issues are significantly more likely to consider they lack information about the impact of chemicals on health. These sources of information would be appropriate for promoting a marketing campaign designed to increase awareness among those who would like to receive more information about the impact on health of chemicals. In a broader context, paying heed to the opportunities provided by the latest technological developments is liable to yield benefits for most 
social categories [51]. Implementing information and education online campaigns for a wider audience in the digital environment can complement the offline campaigns in an effective manner $[49,54,55]$.

Additionally, our findings have shown that people who trust the information provided by the European Union and international organizations are significantly more likely to consider that they lack information regarding the impact of chemicals on health. Therefore, these are highly adequate promoters of information about the impact on health of chemicals used in everyday products.

By indicating the adequate channels, sources of information, and institutions to support an effective campaign for raising public awareness, the present study provides valuable insights for healthcare managers, producers, consumer protection agencies, environmental organizations, and policy-makers, indicating the need for an international effort to inform citizens about the impact on health of chemicals, and the presence of chemicals in consumer products.

Author Contributions: Florin-Alexandru Luca initiated the project, research design, and concepts, as well as the research questions, objectives, and approach, and coordinated the entire study and its team. Claudia-Ioana Ciobanu reviewed the literature and documented the paper. Andreia Gabriela Andrei refined the arguments of the paper and the interpretation of results. Adrian V. Horodnic was in charge of the statistical analysis and methods.

Conflicts of Interest: The authors declare no conflict of interest.

\section{Appendix A}

Table A1. Chemicals that are included in consumers' products, classified as edible goods.

\begin{tabular}{|c|c|c|}
\hline Product & Chemical Substance & Study \\
\hline $\begin{array}{l}\text { Dairy product (milk, yogurt, cheese creams), } \\
\text { processed meats, refreshments, drinks, pasta, } \\
\text { canned-foods, other long-life edible products }\end{array}$ & $\begin{array}{c}\text { Ammonia } \\
\text { Azote /Nitrogen } \\
\text { Phosphorus } \\
\text { Antibiotics sulfonamides } \\
\text { Bovine Somatotropin } \\
\text { Polychlorinated dibenzo-p-Dioxins } \\
\text { Polychlorinated dibenzofurans (PCDD/Fs) } \\
\text { Dioxin-like PCBs (DLPCBs) } \\
\text { Benzoic acid } \\
\text { Sulfate } \\
\text { Hydrogen sulfide }\end{array}$ & [6-9] \\
\hline Furniture and home-based industrial products & $\begin{array}{c}\text { Limonene } \\
\text { Linalool } \\
\text { Citronellol } \\
\text { Cinnamic aldehyde (cinnamal) } \\
\text { Ainnamic alcohol } \\
\text { A-amylcinnamic aldehyde (amyl cinnamal) } \\
\text { Propylene glycol } \\
\text { Glycol ethers } \\
\text { Aldehydes } \\
\text { Methyl-alkanes } \\
\text { Diisocyanates } \\
\text { Organic acid anhydrides } \\
\text { Styrene } \\
\text { Hydroquinone formaldehyde } \\
\text { Ethanol } \\
\text { Phenol }\end{array}$ & [10-13] \\
\hline Buildings and construction industry & $\begin{array}{c}\text { Asbestos } \\
\text { Formaldehyde } \\
\text { Di-isocyanates } \\
\text { Flame retardants } \\
\text { Silica }\end{array}$ & [14-17] \\
\hline
\end{tabular}


Table A1. Cont.

\begin{tabular}{ccc}
\hline Product & Chemical Substance & Study \\
\hline & Methane & \\
Agricultural products and pests management & Cadmium & {$[7,18]$} \\
& Fungicides & Carbon \\
Nitrogen & Potassium Chloride & [19-21] \\
Polish and other products of domestic use & Polyacrylic acid homopolymers & \\
& Formaldehyde & \\
& Benzoic acid & Acrylamide \\
& Lead & Toluene \\
\hline Lubricants and oil derivatives & Glycerol & Esters \\
& Amides & Amines \\
\end{tabular}

Table A2. Legislation framework in the European Union applied to rational use of chemicals in consumer products (main laws, directives, and regulations).

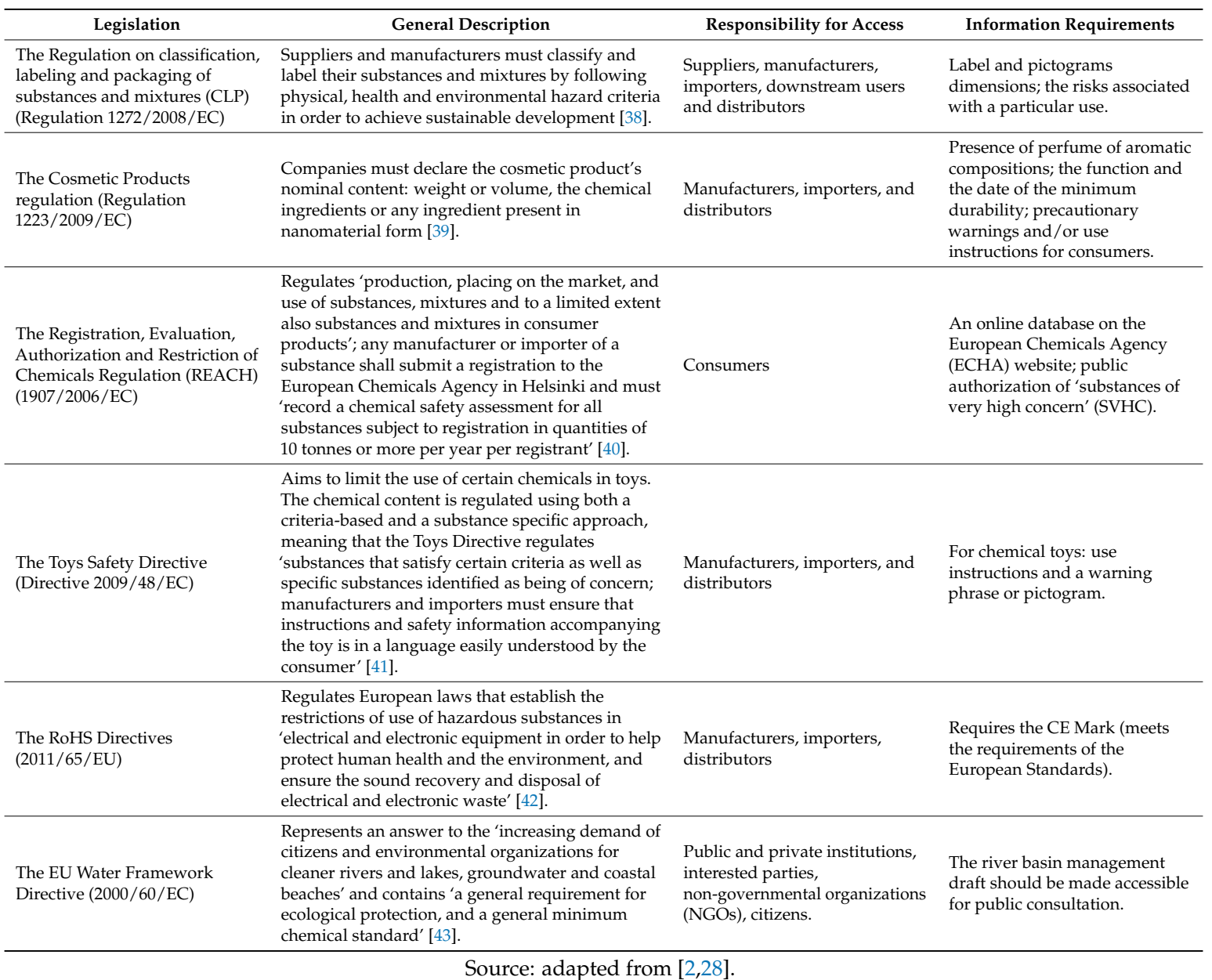




\section{References}

1. European Commission. Attitudes of European Citizens towards the Environment (Report); European Commission: Brussels, Belgium, 2014.

2. Molander, L.; Rudén, C. Narrow-and-sharp or broad-and-blunt-Regulations of hazardous chemicals in consumer products in the European Union. Regul. Toxicol. Pharm. 2012, 62, 523-531. [CrossRef] [PubMed]

3. Bengtsson, G. Regulating chemical risks. In Eriksson. Regulating Chemical Risks: European and Global Challenges; Gilek, M., Rudén, C., Eds.; Springer: London, UK, 2010.

4. Molander, L.; Breitholtz, M.; Andersson, P.L.; Rybacka, A.; Rudén, C. Are chemicals in articles an obstacle for reaching environmental goals?-Missing links in EU chemical management. Sci. Total Environ. 2012, 435-436, 280-289. [CrossRef] [PubMed]

5. Heyen, D.A. Influence of the EU Chemicals Regulation on the US Policy Reform Debate: Is a 'California Effect' within REACH? Transnatl. Environ. Law 2013, 2, 95-115. [CrossRef]

6. Jahed, G.R.; Khaniki, C. Chemical Contaminants in Milk and Public Health Concerns: A Review. Int. J. Dairy Sci. 2007, 2, 104-115. [CrossRef]

7. Aarnink, A.J.A.; Verstegen, M.W.A. Nutrition, key factor to reduce environmental load from pig production. Livest. Sci. 2007, 109, 194-203. [CrossRef]

8. European Commission. Environmental Improvement Potentials of Meat and Dairy Products; Joint Research Centre, Institute for Prospective Technological Studies of Meat and Dairy Product, Office for Official Publications of the European Communities: Luxembourg, 2008; Available online: http:/ /ftp.jrc.es/EURdoc/JRC46650.pdf (accessed on 10 October 2017).

9. Loutfy, N.; Fuerhacker, M.; Tundo, P. Dietary intake of dioxins and dioxin-like PCBs, due to the consumption of dairy products, fish/seafood and meat from Ismailia city, Egypt. Sci. Total Environ. 2006, 370, 1-8. [CrossRef] [PubMed]

10. Rastogi, S.C.; Heydorn, S.; Johansen, J.D.; Basketter, D.A. Fragrance chemicals in domestic and occupational products. Contact Dermat. 2001, 45, 221-225. [CrossRef]

11. Choi, H.; Schmidbauer, N.; Sundell, J.; Hasselgren, M.; Spengler, J.; Bornehag, C. Common Household Chemicals and the Allergy Risks in Pre-School Age Children. PLoS ONE 2010, 5, e13423. [CrossRef] [PubMed]

12. Sherriff, A.; Farrow, A.; Golding, J.; Team, T.A.; Henderson, J. Frequent use of chemical household products is associated with persistent wheezing in pre-school age children. Thorax 2005, 60, 45-49. [CrossRef] [PubMed]

13. Kwon, K.-D.; Jo, W.-K.; Lim, H.-J.; Jeong, W.-S. Volatile pollutants emitted from selected liquid household products. Environ. Sci. Pollut. Res. 2008, 15, 521-526. [CrossRef] [PubMed]

14. Kibert, C.J.; Sendzimir, J.; Guy, G.B. Construction Ecology: Nature as a Basis for Green Buildings; Routhledge: London, UK; New York, NY, USA, 2002; ISBN 0-203-26075-9.

15. Ortiz, O.; Castells, F.; Sonnemann, G. Sustainability in the construction industry: A review of recent developments based on LCA. Constr. Build. Mater. 2009, 23, 28-39. [CrossRef]

16. Kibert, K.J. Sustainable Construction: Green Building Design and Delivery; John Wiley \& Sons: Hoboken, NJ, USA, 2016; ISBN 9781119055310.

17. Pacheco-Torgal, F. Eco-efficient construction and building materials research under the EU Framework Programme Horizon 2020. Constr. Build. Mater. 2014, 51, 151-162. [CrossRef]

18. Brevik, E.C.; Steffan, J.; Burgess, L.; Cerdà, A. Links between Soil Security and the Influence of Soil on Human Health. In Global Soil Security. Progress in Soil Science; Field, D.J., Morgan, C.L.S., McBratney, A.B., Eds.; Springer: Cham, Switzerland, 2017.

19. European Commission. Polycarboxylates in Detergents; Scientific Committee on Health and Environmental Risks; European Commission: Brussels, Belgium, 2010.

20. European Comission. Opinion on the Use of the Threshold of Toxicological Concern (TTC) Approach for Human Safety Assessment of Chemical Substances with Focus on Cosmetics and Consumer Products. Available online: http:/ / ec.europa.eu/health/scientific_committees/consumer_safety/docs/sccs_o_092.pdf (accessed on 30 December 2017).

21. Becker, M.; Edwards, S.; Massey, E.I. Toxic Chemicals in Toys and Children's Products: Limitations of Current Responses and Recommendations for Government and Industry. Environ. Sci. Technol. 2010, 44, 7986-7991. [CrossRef] [PubMed] 
22. Armylisasa, A.H.N.; Hazirahb, M.F.S. Modification of olefinic double bonds of unsaturated fatty acids and other vegetable oil derivatives via epoxidation: A review. Grasas Aceites 2017, 68. [CrossRef]

23. Ruggieroa, A.; D'Amatob, R.; Merolaa, M.; Valašekc, P.; Müllerc, M. Tribological characterization of vegetal lubricants: Comparative experimental investigation on Jatropha curcas L. oil, Rapeseed Methyl Ester oil, Hydrotreated Rapeseed oil. Tribol. Int. 2017, 109, 529-540. [CrossRef]

24. MasCsey, R.I.; Hutchins, J.G.; Becker, M.; Tickner, J. Toxic Substances in Articles: The Need for Information; The Nordic Council of Ministers: Copenhagen, Denmark, 2008; ISBN 978-92-893-1778-8.

25. Ågerstrand, M.; Beronius, A. Weight of evidence evaluation and systematic reviewin EU chemical risk assessment: Foundation is laid but guidance is needed. Environ. Int. 2015, 92-93, 590-596. [CrossRef] [PubMed]

26. Bollheimer, M. The new consumer advocates for safer chemicals: Mandating healthy products. J. Bus. Strategy 2015, 36, 3-10. [CrossRef]

27. European Centre for Ecotoxicology and Toxicology of Chemicals (ECETOC). Envinronmental Impact Assessment for Socio-Economic Analysis of Chemicals: Principles and Practice; European Centre for Ecotoxicology and Toxicology of Chemicals: Brussels, Belgium, 2011.

28. Molander, L.; Cohen, A.K. EU and US Regulatory Approaches to Information on Chemicals in Products: Implications for Consumers. Eur. J. Risk Regul. 2012, 3, 521-533. [CrossRef]

29. Kovacs, D.C. Perceptions of Chemicals in Society: Three Perspectives. Master's Thesis, Carnegie Mellon University, Pittsburgh, PA, USA, 2003.

30. Eyles, J.; Kathi, W.; Mu, L.; Keller-Olaman, S.; Elliott, S. What people think about the environment and its relationship to their health: Perceptions of health at different scales of environment in Hamilton, Ontario. Local Environ. 2009, 14, 981-998. [CrossRef]

31. Shanmugasundaram, P.; Maheshwari, U.T.N.; Aanandhi, V.; Praveen, D. Cancer awareness exposure and attitude towards the common chemical. Int. J. Res. Pharm. Sci. 2017, 8, 49-53.

32. Vogel, S.A. The Politics of Plastics: The Making and Unmaking of Bisphenol A "Safety". Am. J. Public Health 2009, 99, 559-566. [CrossRef] [PubMed]

33. Lahl, U.; Zeschmar-Lahl, B. Risk based management of chemicals and products in a circular economy at a global scale (risk cycle), extended producer responsibility and EU legislation. Environ. Sci. Eur. 2013, 25, 2-12. [CrossRef]

34. Rotariu, M.; Turnea, M.; Ilea, M.; Arotaritei, D.; Ionite, A.C.; Gheorghita, A. Statistical Analysis and Simulation of Orthostatic Position by Means of the Pedometer in Patients with Hyperkyphosis. Rev. Res. Soc. Int. 2017, 59, 209-221.

35. Velmurugan, S.M. Sustainable perspectives on energy consumption, EMRF, environment, health and accident risks associated with the use of mobile phones. Renew. Sustain. Energy Rev. 2017, 67, 192-206. [CrossRef]

36. Røpke, I. Consumption in ecological economics. Economics. Internet Encyclopaedia of Ecological Economics. Technical University: Denmark, 2005. Available online: http:/ /isecoeco.org/pdf/consumption_in_ee.pdf (accessed on 10 August 2017).

37. Orford, R.; Crabbe, H.; Hague, C.; Schaper, A.; Duarte-Davidson, R. EU alerting and reporting systems for potential chemical public health threats and hazards. Environ. Int. 2014, 72, 15-25. [CrossRef] [PubMed]

38. European Commission. Regulation (EC) No 1272/2008 of the European Parliament and of the Council, of 16 December 2008, on Classification, Labelling and Packaging of Substances and Mixtures, Amending and Repealing Directives 67/548/EEC and 1999/45/EC, and Amending Regulation (EC) No 1907/2006. Available online: http:/ / eur-lex.europa.eu/LexUriServ/LexUriServ.do?uri=OJ:L:2008:353:0001:1355:en:PDF (accessed on 12 December 2017).

39. European Commission. Regulation (EC) No 1223/2009 of the European Parliament and of the Council, of 30 November 2009, on Cosmetic Products. Available online: http:/ / eur-lex.europa.eu/LexUriServ / LexUriServ.do?uri=OJ:L:2009:342:0059:0209:en:PDF (accessed on 12 December 2017).

40. EU-OSHA. European Union Information Agency for Occupational Safety and Health. Available online: https: / / osha.europa.eu/en/legislation/directives/regulation-ec-no-1907-2006-of-the-europeanparliament-and-of-the-council (accessed on 12 December 2017).

41. European Commission. Growh. Available online: http://ec.europa.eu/growth/sectors/toys/safety_en (accessed on 10 December 2017). 
42. European Commission. Envinronment. Available online: http://ec.europa.eu/environment/waste/rohs_ eee/legis_en.htm (accessed on 10 December 2017).

43. European Commission. The EU Water Framework Directive-Integrated River Basin Management for Europe. Available online: http:/ / ec.europa.eu/environment/water/water-framework/index_en.html (accessed on 23 December 2017).

44. European Commission. Eurobarometer 81.3 (April-May 2014); TNS OPINION, ZA5914, Data Set Version 2.0.0; GESIS, Cologne: Brussels, Belgium, 2014. [CrossRef]

45. Solon, G.; Haider, S.J.; Wooldridge, J. What are we weighting for? J. Hum. Res. 2013, 50, 301-316. [CrossRef]

46. Williams, C.C.; Horodnic, A.V. Rethinking informal payments by patients in Europe: An institutional approach. Health Policy 2017, 121, 1053-1062. [CrossRef] [PubMed]

47. Williams, C.C.; Horodnic, I.A.; Horodnic, A.V. Who is making informal payments for public healthcare in East-Central Europe? An evaluation of socio-economic and spatial variations. Eastern J. Eur. Stud. 2016, 7, 49-61.

48. Williams, C.C.; Horodnic, I.A. Marginalisation and participation in the informal economy in Central and Eastern European nations. Post-Communist Econ. 2015, 27, 153-169. [CrossRef]

49. Andrei, A.G.; Gazzola, P.; Zbuchea, A.; Alexandru, V.A. Modeling socially responsible consumption and the need for uniqueness: A PLS-SEM approach. Kybernetes 2017, 46, 1325-1340. [CrossRef]

50. Vătămănescu, E.M.; Gazzola, P.; Dincă, V.M.; Pezzetti, R. Mapping Entrepreneurs' Orientation towards Sustainability in Interaction versus Network Marketing Practices. Sustainability 2017, 9, 1580. [CrossRef]

51. Steg, L.; Bolderdijk, J.W.; Keizer, K.; Perlaviciute, G. An integrated framework for encouraging pro-environmental behaviour: The role of values, situational factors and goals. J. Environ. Psychol. 2014, 38, 104-115. [CrossRef]

52. Chen, Y.S.; Chang, C.H. Enhance green purchase intentions: the roles of green perceived value, green perceived risk and green trust. Manag. Decis. 2012, 50, 502-520. [CrossRef]

53. Vătămănescu, E.-M.; Pînzaru, F.; Andrei, A.G.; Zbuchea, A. Investigating SMES Sustainability with Partial Least Squares Structural Equation Modelling. Transform. Bus. Econ. 2016, 15, 259-273.

54. Andrei, A.G.; Zait, A.; Vătămănescu, E.M.; Pînzaru, F. Word of mouth generation and brand communication strategy: Findings from an experimental study explored with PLS-SEM. Ind. Manag. Data Sustain. 2017, 117, 478-495. [CrossRef]

55. Gazzola, P.; Pezzetti, R.; Nicolescu, L. Consumer Empowerment in the Digital Economy: Availing Sustainable Purchasing Decisions. Sustainability 2017, 9, 693. [CrossRef] 